\title{
The Relationship Between Tourism Income and Financial Development in The Mena Countries
}

\author{
Emirhan YENIŞEHIRLIOĞLU ${ }^{D}{ }_{a}$ Tayfur BAYAT ${ }^{\text {D }} b$ \\ a Alanya Alaaddin Keykubat University, Department of Gastronomy and Clunary Arts, Turkey. emirhan.yenisehirlioglu@alanya.edu.tr \\ b İnönü University, Department of Economy, Malatya, Turkey. tayfur.bayat@inonu.edu.tr
}

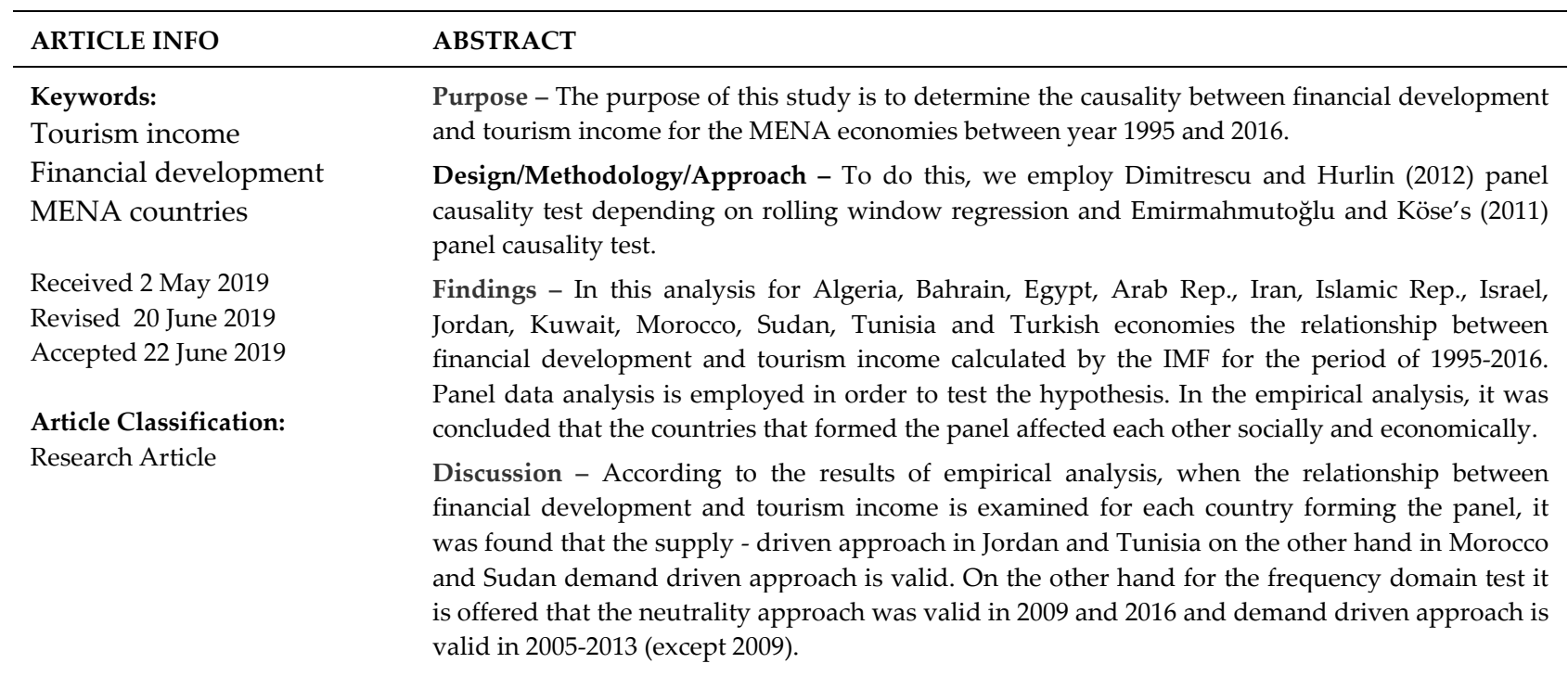

\section{Introduction}

The tourism industry is considered to be one of the largest industries in the world because it contributes to $10.4 \%$ of global GDP ( $\$ 8,272.3$ trillion) and offer a business opportunity for a total of 313 million people. In 2017 , investments in travel and tourism areas were recorded as 882.4 billion dollars. This figure corresponds to $4.5 \%$ of the total investment in the world. (WTTC, 2018).

In 2018, it is seen that 1.326 billion tourists participated in tourism activities and 1 trillion 340 billion dollars' income was obtained from these activities. (UNWTO, 2018). This industry, which has the \%10 percent of people working in the world, has a major economic impact as can be seen from the data.

The fact that the tourism industry has a high multiplier coefficient compared to other industries (Frechtling \& Horvath 1999) increases its importance for the economy of the country derived from tourism activities. Therefore, an increase or decrease in tourism incomes is directly related to economic growth and development. (Martin et all. 2004, Nowak et al., 2007, Durbarry, 2004, Oh, 2005, Fayissa et al., 2008, Lee and Chang, 2008, Sequeira and Nunes 2004, Holzner, 2011 Seetanah, 2011). Similarly, due to the nature of tourism, the inflow of foreign currency to the country is another factor that contributes to economic growth. (Balaguer \& Cantavella 2002).

It has shown by the studies that economic growth is also correlated with financial development. (Demetriades and Hussein, 1996, Gregorio and Guidotti, 1995, Khan and Senhadji, 2003, Hassan et al., 2011, Kumar, 2011). This correlation does not work in a unilateral way, but contributes to economic growth in financial development. So much so that a $10 \%$ financial development reflected a $2.7 \%$ growth in the economy. (Hassan et all. 2011). 
When the relationship between tourism income and financial development is examined, there is a positive correlation as well. Kumar and Kumar (2013) found that tourism activities had an impact on financial development. It is also known that the financial crises are reflected in the tourism industry. (Sheldon and Dwyer, 2010, Smeral, 2009, Wei 2010, Song, and Lin, 2010, Henderson, 1999). In this context, it can be foreseen that there is a relationship between tourism revenues and financial development.

Within the scope of this study, the relationship between the tourism revenues of the MENA countries and the financial developments they experienced during the 1995-2016 period was wanted to be explained.

The word MENA was created by combining the initials of Middle-East-North-Africa. Mena countries are usually expressed as Algeria Bahrain, Egypt, Iran (Islamic Republic of), Iraq, Israel, Jordan, Kuwait, Lebanon, Libya, Morocco, Oman, Qatar, Saudi Arabia, State of Palestine, Syrian Arab Republic, Tunisia, United Arab Emirates, Yemen and Turkey. However, this data included Algeria, Bahrain, Egypt, Arab Republic, Iran, Islamic Republic, Israel, Jordan, Kuwait, Morocco, Sudan, Tunisia and Turkey from MENA countries.

MENA countries, which host more than $60 \%$ of the world's oil reserves, have started to work to reduce their dependence on oil as a result of recent political and social changes. For example, according to OPEC data (2018), Saudi Arabia, the world's second largest oil reserve, is trying to reduce its dependence on oil in the economic sense of its targets for 2030 (Khan, 2016). In this context, revenues from tourism activities are important in terms of building the economic stability of the countries in the region independently of oil.

\section{Methodology and Empirical Results}

In the analysis Algeria, Bahrain, Egypt, Arab Rep., Iran, Islamic Rep., Israel, Jordan, Kuwait, Morocco, Sudan, Tunisia and Turkey economies are considered ${ }^{1}$ For financial development index ${ }^{2}$ (FD) the data gained from IMF for the period 1995-2016. On the other hand, Tourism revenue is gained from World Bank Database (TI). The natural logarithms of the variables are considered for the analysis in order to avoid volatile variance problem.

\section{Graph 1. Variables FD and TI}

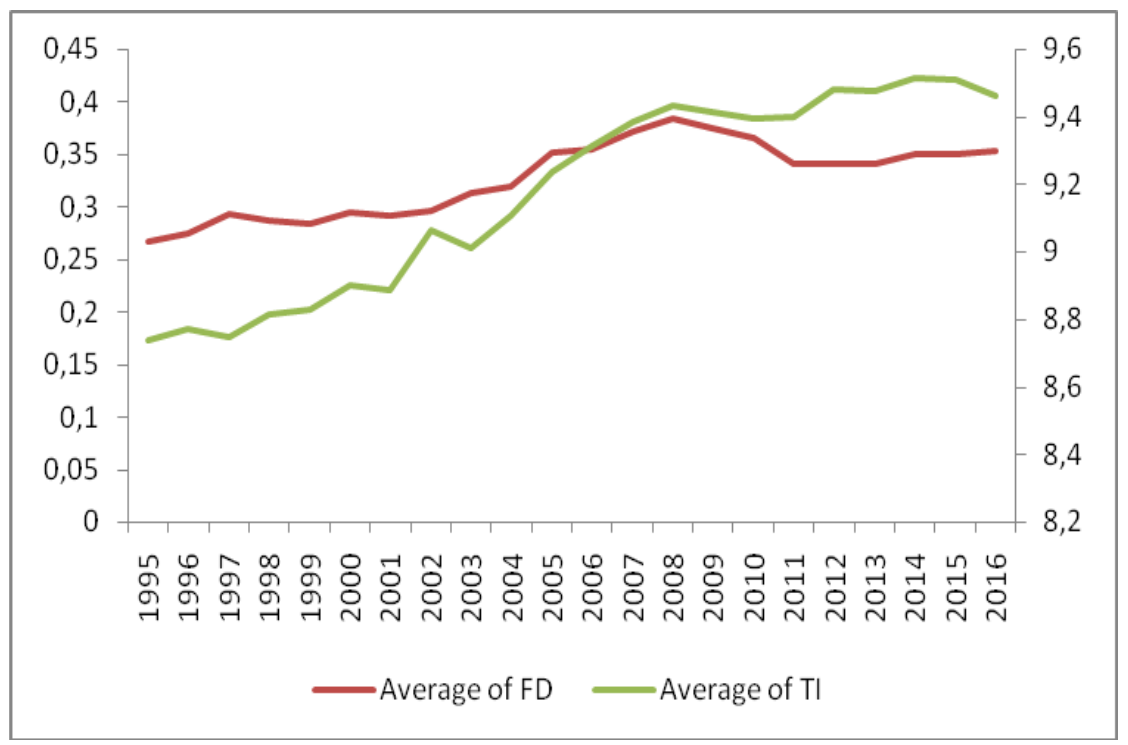

Graph 1 presents the arithmetic averages of the countries that make up the panel. It is seen that both tourism income and financial development have been increasing and acting in a co-integrated manner over the years. In panel data analysis, the cross-sectional dependency is tested to determine that each work is related to each other before the unit root test is performed. If there is no cross-sectional dependency, 1st generation unit root tests, if there is a cross-sectional dependence, 2nd generation unit root tests are employed. In panel data analysis, Peseran (2004) CDLM, Breusch-Pagan CDLM1, Peseran (2004) CDLM2 tests are used to test the

\footnotetext{
${ }^{1}$ Some countries were excluded from the empirical analyzes since Libya's 2011-2016, Qatar 1995-1998 and 2007-2010, Saudi Arabia 1995-2002, Syrian Arab Republic's 2012-2016 tourism revenues were absent.

${ }^{2}$ Please refer Sahay et al. (2015) for detailed information about financial development index.
} 
cross-sectional dependence. CDLM1 and CDLM2 are used when T>N, when the time dimension is greater than the horizontal size. The CDLM test is used when $\mathrm{N}>\mathrm{T}$ is greater than the horizontal size time dimension.

Table 1. Cross-Section Dependency Test Results

\begin{tabular}{ccccc}
\hline Constant Model & \multicolumn{2}{c}{$\operatorname{lnFD}$} & \multicolumn{2}{c}{$\operatorname{lnTI}$} \\
& Statistic & p-value & Statistic & p-value \\
\hline$C D_{l m}(\mathrm{BP}, 1980)$ & 99.790 & $0.00^{* * *}$ & 72.082 & $0.061^{*}$ \\
$C D_{l m}$ (Pesaran, 2004) & 4.271 & $0.00^{* * *}$ & 1.629 & $0.052^{*}$ \\
$C D \quad$ (Pesaran, 2004) & -1.504 & $0.066^{*}$ & -1.625 & $0.052^{*}$ \\
$L M_{a d j}($ PUY, 2008) & 2.461 & $0.00^{* * *}$ & 6.283 & $0.00^{* * *}$ \\
\hline
\end{tabular}

Notes: In the model lag length is considered as (pi) 1. In the cross sectional dependence tests, the null hypothesis is; there is no cross-sectional dependence and the alternative hypothesis is; there is cross-sectional dependency. The figures which is ${ }^{* * *},{ }^{* *}, *$ show $1 \%, 5 \%$ and $10 \%$ levels, respectively

When the probability values are taken into consideration, alternative hypothesis is considered that there is a cross-sectional dependence. The 2nd generation unit root tests are cross-sectionally augmented Dickey and Fuller (CADF) tests which can be tested individually for each country and can be applied when the time dimension is larger than the horizontal size (T>N). In the CADF test, the null hypotheses suggest the series carry a serial unit root and the alternative hypothesis is that they do not carry a serial unit root. If the CADF test statistic is less than the critical value, it indicates that the country series is stationary. If the CADF test value is greater than the critical values, the null hypothesis is considered and it has the non-stationary process characteristics of the series of that country. In the constant model, for the financial development index Bahrain and Israel, for the tourism revenue variable Turkey's data are stationary in the level. On the other hand, for the constant and trend model Turkey and Bahrain are stationary. ${ }^{3}$ The tests developed by Breusch and Pagan (1980), Peseran (2004) and Peseran et al. (2008) both suggest that there is a cross sectional dependency in the series of selected the countries. ${ }^{4}$

\section{Table 2. Emirmahmutoğlu and Köse (2011) Panel Causality Test Results}

\begin{tabular}{cccccc}
\hline Country & Lag & $\begin{array}{c}\text { FD } \neq \text { TI } \\
\text { Wald }\end{array}$ & p-value & $\begin{array}{c}\text { TI } \neq>\text { FD } \\
\text { Wald }\end{array}$ & p-value \\
\hline Algeria & 3 & 4.114 & 0.249 & 1.267 & 0.736 \\
Bahrain & 3 & 4.019 & 0.259 & 3.870 & 0.275 \\
Egypt, Arab Rep. & 1 & 1.862 & 0.172 & 0.014 & 0.903 \\
Iran, Islamic Rep. & 3 & 2.623 & 0.453 & 4.262 & 0.234 \\
Israel & 1 & 0.168 & 0.681 & 1.646 & 0.199 \\
Jordan & 1 & 3.969 & $0.046^{* *}$ & 1.101 & 0.293 \\
Kuwait & 2 & 3.576 & 0.167 & 3.702 & 0.157 \\
Morocco & 3 & 5.258 & 0.153 & 6.648 & $0.084^{*}$ \\
Sudan & 2 & 1.486 & 0.475 & 12.721 & $0.00^{* * *}$ \\
Tunisia & 1 & 4.044 & $0.044^{* *}$ & 0.359 & 0.548 \\
Turkey & 2 & 0.023 & 0.988 & 1.751 & 0.416 \\
\hline Fisher & & $\mathbf{3 2 . 5 4 9}$ & $\mathbf{0 . 0 6 8}$ & $\mathbf{3 6 . 2 9 3}$ & $\mathbf{0 . 0 2 8 ^ { * * }}$ \\
\hline
\end{tabular}

Notes: The null hypothesis of the test is there is no causality. The figures which is ${ }^{* * *},{ }^{* *},{ }^{*}$ show $1 \%, 5 \%$ and $10 \%$ levels, respectively

\footnotetext{
${ }^{3}$ CADF unit test results are presented in Appendix I.

${ }^{4}$ Cross Sectional Dependency test results are presented in Appendix II.
} 
According to the results of the causality test developed by Emirmahmutoğlu and Köse (2011), there is a causality from financial development to tourism income in Jordan and Tunisia and the supply - driven approach proposed by Schumpeter $(1912,1934)$ is valid. In Morocco and Sudan, there is causality from tourism income to financial development and the supply - driven approach proposed by Robinson (1952) is valid. The causality relation is observed in economies with low share of tourism revenues in GDP and relatively low financial development. Financial development contributes to economic growth by increasing the efficiency of tourism investments, reducing transaction costs and changing savings behavior. In addition, financial development creates indirect effects on tourism revenues if the level of financial development is above a certain threshold (Ohlan, 2017, Yand and Shi, 2014). It is seen that the tourism industry in Jordan and Tunisia is in the stage of emergence. Therefore, in order to support tourism infrastructure investments, the public sector should allocate more shares to the tourism sector.

Table 3. Dimitrescu and Hurlin (2012) Panel Causality Test Depending on Rolling Window Regression

\begin{tabular}{ccccc}
\hline Date & W Stat & $\begin{array}{c}\text { FD } \neq>\text { TI } \\
\text { p-value }\end{array}$ & W Stat & $\begin{array}{c}\text { TI } \neq>\text { FD } \\
\text { p-value }\end{array}$ \\
\hline 2004 & 0.055 & 0.814 & 0.940 & 0.334 \\
2005 & 2.343 & 0.404 & 3.361 & $0.094^{*}$ \\
2006 & 1.940 & 0.662 & 3.396 & $0.075^{*}$ \\
2007 & 1.457 & 0.966 & 3.666 & $0.032^{* *}$ \\
2008 & 2.188 & 0.496 & 6.914 & $0.00^{* * *}$ \\
2009 & 4.490 & $0.00^{* * *}$ & 7.444 & $0.00^{* * *}$ \\
2010 & 1.586 & 0.931 & 4.316 & $0.00^{* * *}$ \\
2011 & 2.848 & 0.182 & 3.331 & $0.07^{*}$ \\
2012 & 1.254 & 0.808 & 3.835 & $0.02^{* *}$ \\
2013 & 2.211 & 0.481 & 3.499 & $0.048^{* *}$ \\
2014 & 3.090 & 0.115 & 1.616 & 0.908 \\
2015 & 2.542 & 0.302 & 2.497 & 0.324 \\
2016 & 4.685 & $0.00^{* * *}$ & 5.931 & $0.00^{* * *}$ \\
\hline
\end{tabular}

Notes: The null hypothesis of the test is there is no causality. The figures which is ${ }^{* * *},{ }^{* *},{ }^{*}$ show $1 \%, 5 \%$ and $10 \%$ levels, respectively

The causality test developed by Dimitrescu and Hurlin (2012) takes into account the cross-sectional dependence of the panel forming countries. The cross section size is smaller than the time dimension and is used in unbalanced panels. The first nine observations from the beginning of the analysis period were used for the rolling window regression. Then, according to the same procedure, cross-sectional dependence and CADF unit root test were performed for each data interval. Panel causality test developed by Dimitrescu and Hurlin (2012) was applied by taking the lag length as one. Accordingly, for all the countries that formed the panel in 2009 and 2016, there is a bi-directional causality between the financial development and tourism income, which was previously suggested by Demetriades and Hussein (1996), and the hypothesis of neutrality is valid. In 2005-2013 and 2016, there is causality from tourism income to financial development. In addition, there is causality from financial development to economic growth in 2009 and 2016. Because most of the countries that make up the panel are in the development stage of tourism, optimization of tourism industry structure, improvement of service quality, development of tourism products and innovation of marketing models bring higher conditions for financial structure. As Song and Lin (2010) discusses the global economic crisis in 2008 and the decline in global economic growth rates in 2016, there is a bi-directional causality between tourism income and financial development. In addition, the financial sector is helping to improve the tourism market in the market inefficiency due to the decrease in tourism revenues. The tourism sector should diversify its funding channels in order to meet its financial needs, receive direct financial support and diversify its financial supply structure.

\section{Conclusion}

The concept of sustainable growth is prominent due to the depletion of natural resources, environmental degradation and the imbalanced development of the ecological system. For this reason, tourism revenues, which is one of the most important determinants of economic growth, is integrated into the financial system 
and creates efficiency in resource allocation. Financial development is important in channeling savings to investments. In this analysis for Algeria, Bahrain, Egypt, Arab Rep., Iran, Islamic Rep., Israel, Jordan, Kuwait, Morocco, Sudan, Tunisia and Turkish economies the relationship between financial development and tourism income calculated by the IMF for the period of 1995-2016. Panel data analysis is employed in order to test the hypothesis. In the empirical analysis, it was concluded that the countries that formed the panel affected each other socially and economically. When the relationship between financial development and tourism income is examined for each country forming the panel, it was found that the supply - driven approach in Jordan and Tunisia on the other hand in Morocco and Sudan demand driven approach is valid. On the other hand for the frequency domain test it is offered that the neutrality approach was valid in 2009 and 2016 and demand driven approach is valid in 2005-2013 (except 2009).

\section{REFERENCES}

Balaguer, J., \& Cantavella-Jorda, M. (2002). Tourism as a long-run economic growth factor: the Spanish case. Applied economics, 34(7), 877-884.

Breusch, T., Pagan, A., 1980. The Lagrange multiplier test and its application to model specification in econometrics. Rev. Econ. Stud. 47, 239-253.

Demetriades P. O., H. A. Khaled (1996), “Does Financial Development Cause Economic Growth? Time Series Evidence From 16 Countries", Journal Of Development Economics, 51(2), 1996, 387-411

Demetriades, P. O., \& Hussein, K. A. (1996). Does financial development cause economic growth? Timeseries evidence from 16 countries. Journal of development Economics, 51(2), 387-411.

Dumitrescu, E. I., \& Hurlin, C. (2012). Testing for Granger non-causality in heterogeneous panels. Economic Modelling, 29(4), 1450-1460.

Durbarry, R. (2004). Tourism and economic growth: the case of Mauritius. Tourism Economics, 10(4), 389-401.

Emirmahmutoğlu, F. And Kose, N. (2011), “Testing for Granger Causality in Heterogeneous Mixed Panels”, Economic Modelling , 28, 870-876.

Fayissa, B., Nsiah, C. and Tadasse, B. (2008) 'Impact of tourism on economic growth and development in Africa', Tourism Economics, Vol. 14, No. 4, pp.807-818.

Frechtling, D. C., \& Horvath, E. (1999). Estimating the multiplier effects of tourism expenditures on a local economy through a regional input-output model. Journal of travel research, 37(4), 324-332.

Gregorio, J., \& Guidotti, P. E. (1995). Financial development and economic growth. World development, 23(3), 433-448.

Hassan, M. K., Sanchez, B., \& Yu, J. S. (2011). Financial development and economic growth: New evidence from panel data. The Quarterly Review of economics and finance, 51(1), 88-104.

Henderson, J. C. (1999). Asian tourism and the financial Indonesia and Thailand compared. Current Issues in Tourism, 2, 294-303.

Holzner, M. (2011) ‘Tourism and economic development: the beach disease?' Tourism Management, Vol. 32, No. 4, pp.922-933.

Khan, M. (2016). Saudi Arabia's Vision 2030. Defence Journal, 119, 36-42.

Khan, M. and Senhadji, A. (2003) 'Financial development and economic growth: a review and new evidence', Journal of African Economies, Vol. 12, No. 2, pp.89-110.

Kumar, R. R., \& Kumar, R. (2013). Exploring the developments in urbanisation, aid dependency, sectoral shifts and services sector expansion in Fiji: a modern growth perspective. Global Business and Economics Review, 15, 371-395.

Kumar, R.R. (2011) 'Do remittances, exports and financial development matter for economic growth? A case study of Pakistan using bounds approach', Journal of International Academic Research, Vol. 11, No. 1, pp.18-26. 
Lee, C.C. and Chang, C.P. (2008) 'Tourism development and economic growth: a closer look at panels', Tourism Management, Vol. 29, No. 1, pp.180-192.

Martin, J. L., Morales, N., \& Scarpa, R. (2004). Tourism and economic growth in Latin American countries: A panel data approach.

Nowak, J.Q., Sahli, M. and Cortes-Jimenez, I. (2007) 'Tourism, capital good imports and economic growth: theory and evidence for Spain', Tourism Economics, Vol. 13, No. 4, pp.515-536.

Oh, C. O. (2005). The contribution of tourism development to economic growth in the Korean economy. Tourism management, 26(1), 39-44.

Ohlan, R. (2017) The relationship between tourism, financial development and economic growth in India. Future Bus. J., 3, 9-22.

OPEC (2018) OPEC Annual Statistical Bulletin, Vienna

Pesaran, Hasem, M., (2004), "General Diagnostic Tests for Cross Section Dependence in Panels", Working Paper No:0435, University of Cambridge.

Pesaran, M. H. (2007). A simple panel unit root test in the presence of cross-section dependence. Journal of Applied Econometrics, 22(2), 265-312.

Pesaran, M. H., \& Yamagata, T. (2008). Testing slope homogeneity in large panels. Journal of Econometrics, 142(1), 50-93.

Pesaran, M.H., Ullah, A., Yamagata, T., 2008. A bias-adjusted LM test of error cross section independence. Econometrics Journal 11, 105-127.

Robinson J., (1952), The Rate Of Interest And Other Essays, London: Macmillan.

Sahay, R., Čihák, M., N'Diaye, P., \& Barajas, A. (2015). Rethinking financial deepening: Stability and growth in emerging markets. Revista de Economía Institucional, 17(33), 73-107.

Schumpeter, J. A., (1912), The Theory Of Economic Development, Cambridge: Harvard University Press.

Schumpeter, J. A., (1934), The Theory Of Economic Development; An Inquiry İnto Profits, Capital, Credit, Interest, And The Business Cycle, Çev. Opie, R. Cambridge: Harvard University Press.

Seetanah, B. (2011) 'Assessing the dynamic economic impact of tourism for island economies', Annals of Tourism Research, Vol. 38, No. 1, pp.291-308.

Sequeira, T. N., \& Maçãs Nunes, P. (2008). Does tourism influence economic growth? A dynamic panel data approach. Applied Economics, 40(18), 2431-2441.

Sheldon, P., \& Dwyer, L. (2010). The global financial crisis and tourism: Perspectives of the academy. Journal of Travel Research, 49, 3-4.

Smeral, E. (2009). The impact of the financial and economic crisis on European tourism. Journal of Travel Research, 48(1), 3-13.

Song, H., \& Lin, S. (2010). Impacts of the financial and economic crisis on tourism in Asia. Journal of Travel Research, 49(1), 16-30.

Song, H.; Lin, S. (2010) Impacts of the financial and economic crisis on tourism in Asia. J. Travel Res., 49, $16-$ 30.

UNWTO, T. O. (2018). Tourism Highlights, 2018 Edition. World.

W. T. T. C. (2017). Tourism: Global Economic Impact \& Issue 2018. WTTC: London, UK.

Wei, S. H. I. (2010). The Influence of the Financial Crisis on European City Tourism as Predicted by Tourism Expert $s$ (Doctoral dissertation, Master's Thesis, MODUL University, Austria).

Westerlund, J. (2007). Testing for error correction in panel data. Oxford Bulletin of Economics and statistics, 69(6), 709-748.

Yang, J.C.; Shi, R. Comparison of Dynamic Effects of Financial Support for Tourism Industry Development: A Case Study of Guizhou and Zhejiang Provinces. Soc. Sci. 2014, 6, 88-92. 
Appendix I.

CADF Unit Root test Results

\begin{tabular}{|c|c|c|c|c|}
\hline & \multicolumn{2}{|r|}{ Constant } & \multicolumn{2}{|c|}{ Constant and Trend } \\
\hline & Lags & CADF-stat & Lags & CADF-stat \\
\hline \multicolumn{5}{|l|}{$\underline{F D}$} \\
\hline Algeria & 1 & -1.317 & 2 & -2.344 \\
\hline Bahrain & 1 & $-4.079^{* *}$ & 1 & $-4.229^{* *}$ \\
\hline Egypt, Arab Rep. & 1 & -1.579 & 1 & -2.909 \\
\hline Iran, Islamic Rep. & 1 & -0.570 & 4 & -2.266 \\
\hline Israel & 1 & $-3.552^{* *}$ & 1 & -2.295 \\
\hline Jordan & 1 & -1.074 & 1 & -1.551 \\
\hline Kuwait & 1 & -2.523 & 1 & -2.852 \\
\hline Morocco & 1 & -2.153 & 3 & -2.586 \\
\hline Sudan & 1 & $-3.198^{*}$ & 4 & -2.666 \\
\hline Tunisia & 1 & -1.542 & 2 & -1.599 \\
\hline Turkey & 1 & -1.567 & 1 & $-3.875^{* *}$ \\
\hline Panel & & -2.105 & & -2.652 \\
\hline \multicolumn{5}{|l|}{$\underline{T I}$} \\
\hline Algeria & 1 & -2.204 & 1 & -2.097 \\
\hline Bahrain & 1 & -1.036 & 2 & -0.164 \\
\hline Egypt, Arab Rep. & 1 & 0.379 & 1 & -1.767 \\
\hline Iran, Islamic Rep. & 2 & -2.971 & 4 & -3.142 \\
\hline Israel & 1 & -1.987 & 1 & -1.494 \\
\hline Jordan & 2 & -2.743 & 2 & -2.442 \\
\hline Kuwait & 1 & -1.879 & 3 & -1.451 \\
\hline Morocco & 1 & -0.086 & 3 & 0.634 \\
\hline Sudan & 1 & -2.419 & 1 & -2.493 \\
\hline Tunisia & 1 & -0.109 & 1 & -2.543 \\
\hline Turkey & 1 & $-3.126^{*}$ & 1 & -3.064 \\
\hline Panel & & -1.653 & & -1.820 \\
\hline
\end{tabular}

Note: The maxium lag length is determined as 4 and the optimal lag length is determined according to Schwarz information criteria. CADF statistics critical value for the constant model -4.11 (\%1), -3.36 (\%5) and 2.97 (\%10) respectively (Pesaran 2007, table I(b), p:275) ; for the constant and trend model $-4.67(\% 1),-3.87$ $(\% 5)$ and -3.49 (\%10) (Pesaran 2007, table I(c), p:276). Panel statistics critical value for the constant model 2.57 (\%1), -2.33 (\%5) and -2.21 (\%10) (Pesaran 2007, table II(b), p:280) for the constant and trend model -3.10 (\%1), -2.86 (\%5) ve -2.73 (\%10) (Pesaran 2007, table II(c), p:281). CIPS is the mean of individual crosssectionally augmented ADF statistics (CADF). The figures which is ${ }^{* * *},{ }^{* *},{ }^{*}$ show $1 \%, 5 \%$ and $10 \%$ levels, respectively 
Appendix II.

\section{Cross-Section Dependency and Homogenity Test Results}

Regression Model:

$$
\operatorname{lnT\mathrm {TI}_{it}}=\alpha_{i}+\beta_{1 i} \ln \mathrm{FD}_{i t}+\varepsilon_{i t} \quad \text { Statistic } \quad \mathrm{p} \text {-value }
$$

Cross-section dependency tests:

$\begin{array}{lrr}L M(\mathrm{BP}, 1980) & 169.004 & 0.00^{* * *} \\ C D_{l m} \text { (Pesaran, 2004) } & 10.870 & 0.00^{* * *} \\ C D \quad \text { (Pesaran, 2004) } & 7.866 & 0.00^{* * *} \\ L M_{a d j}(\text { PUY, 2008) } & & \\ & 20.066 & 0.00^{* * *}\end{array}$

Homogeneity tests:

$\begin{array}{lll}\tilde{\Delta} & 12.701 & 0.00^{* * *} \\ \tilde{\Delta}_{a d j} & 13.620 & 0.00^{* * *}\end{array}$

Notes: The figures which is ${ }^{* * *}, * *, *$ show $1 \%, 5 \%$ and $10 \%$ levels, respectively 